\title{
Micronutrient Concentrations and Environmental Concerns in an Intensively Cultivated Typic Dystrandept in Mount Bambouto, Cameroon
}

\author{
D. Bitondo, F. O. Tabi, S. S. A. Kengmegne, M. Ngoucheme, A. D. MvondoZe
}

Department of Soil Science, University of Dschang, Dschang, Republic of Cameroon.

Email: obenft@yahoo.com

Received July $9^{\text {th }}, 2013$; revised August $7^{\text {th }}, 2013$; accepted August $14^{\text {th }}, 2013$

Copyright (C) 2013 D. Bitondo et al. This is an open access article distributed under the Creative Commons Attribution License, which permits unrestricted use, distribution, and reproduction in any medium, provided the original work is properly cited.

\begin{abstract}
Micronutrient status of top soils $(0-25 \mathrm{~cm})$ collected from intensively cultivated soils (typic dystrandept) in the Bambouto highland of Cameroon was investigated. Thirty-six soil samples were collected within a $100 \mathrm{~m} \times 100 \mathrm{~m}$ grid. 16 of them were analyzed for $\mathrm{pH}$, organic carbon, cation exchange capacity (CEC), Total $\mathrm{N}$ (totN), available $\mathrm{P}$, exchangeable $\mathrm{K}, \mathrm{Ca}$ and $\mathrm{Mg}$, and 36 samples were analyzed for $\mathrm{Cu}, \mathrm{Mn}, \mathrm{Fe}$ and $\mathrm{Zn}$. The status of trace elements was compared with soil critical levels and soil-based risk thresholds, and was declared deficient, sufficient or toxic. The soils were generally, slightly acidic, of high organic and nitrogen status and of adequate concentrations in exchangeable bases and available P. Mean values of $\mathrm{Fe}, \mathrm{Cu}, \mathrm{Mn}$ and $\mathrm{Zn}$ were 58.59, 0.52, 29.20 and $4.99 \mathrm{ppm}$, respectively. Relative to critical levels, $53 \%$ and $8 \%$ of the soils examined were deficient in $\mathrm{Cu}$ and $\mathrm{Zn}$ respectively while in all soils, $\mathrm{Fe}$ and $\mathrm{Mn}$ were above critical levels. The concentrations of the micronutrients investigated (except for $\mathrm{Fe}$ in $3 \%$ of the soils) were lower than toxic thresholds prescribed by European Economic Community (EEC) and the United States Environmental Protection Agency. Farmers' current level of agricultural intensification has no threats on micronutrient toxicity. However, because of $\mathrm{Cu}$ and $\mathrm{Zn}$ deficiency observed in some fields, an analysis of spatial variability is required to guide site specific soil nutrient management. Furthermore, in order to obtain quality produce and protect the environment, a balanced fertilizer recommendation including NPK $+\mathrm{Cu}+\mathrm{Zn}$ is required for intensively cultivated typic dystrandept soils in the Bambouto highlands.
\end{abstract}

Keywords: Trace Metal Concentrations; Micronutrient Toxicity; Agricultural Intensification; Typic Dystrandept

\section{Introduction}

The soils in the Bambouto highlands of Cameroon are of volcanic origin and are intensively used for agriculture. Typic dystrandept is one of such soils which have been cultivated for more than 30 years. The high productivity which is characteristic of this soil has contributed to increased food production, both for export and local consumption. A recent survey revealed that the dominant cropping systems were potato-based and mixed cropping (with more than 5 crops in association) in homestead gardens [1]. In the potato-based cropping system, farmers grow two-to-three crops per year. Continuous cropping on this soil is sustained by heavy dependence on agricultural inputs (herbicides, fungicides, mineral fertilizers, and livestock and poultry manure). The level of agricultural intensification in the Bambouto highland is driven by increasing human population, urbanization in neighboring towns and cities and ready markets. The average population density of the region is more than 200 inhabitants/ $\mathrm{km}^{2}$ [2]. Farmlands are fragmented $(<1 \mathrm{ha} /$ farm $)$ and fallows are inexistent. Because of high demand for potato and vegetables and high economic benefits from potatobased cropping systems, farmers may likely overuse pesticides, herbicides, fertilizers and animal manure to boost crop production in order to meet market demand.

Agrochemicals and animal manure are sources of trace elements which are important environmental pollutants [3]. From the agronomic point of view, trace elements are metals needed in small amounts but essential for normal growth and development of living organisms [4]. Under inappropriate land uses and poor soil management, trace metals can affect the quality of agricultural soils including phytotoxicity and food chain contamination [3, 5]. Because of the aforementioned, concentrations of 
trace elements in synthetic fertilizers, pesticides, soils, crops and manure have been investigated recently by many authors [6-9]. The abnormal increase in $\mathrm{Cu}$ and $\mathrm{Fe}$ in Cardamom soils in India, for example, was attributed to the application of several rounds of micronutrient mixtures and fungicides in cardamom agriculture [10]. Poultry manure may contain relatively high concentrations of several trace metals such as $\mathrm{As}, \mathrm{Co}, \mathrm{Cu}, \mathrm{Fe}, \mathrm{Mn}$, Se and $\mathrm{Zn}[3,11]$. Other studies have shown that crops raised on metal contaminated soil accumulate metals in concentrations excessive enough to cause clinical problems both to humans and animals that consume these metal-rich plants $[3,10,12]$. Benson [12] reported that heavy metal pollution of cultivable agricultural farmlands was increasing and was often associated with anthropogenic sources. In the absence of human influences, background levels of trace elements are relatively low and hence pose little threats to human health [13]. Due to non-biodegradability of heavy metals and because emission (partly by leaching) is far less than anthropogenic inputs, heavy metals steadily accumulate in soils as sinks [14]. Increasing concerns on food safety and environmental quality therefore call for cultivation of quality produce [15]. However, the issue of toxicity is usually merely a matter of quantity with the range varying for each element. Considering fertilizers as sources of trace metal contamination, trace element and heavy metal concentrations of common commercial fertilizers are generally low, but high $\mathrm{P}$ blended fertilizers and pure phosphate fertilizers contain relatively high levels of several elements of potential environmental concern like $\mathrm{Cd}, \mathrm{V}$, $\mathrm{As}, \mathrm{Mo}, \mathrm{Cr}, \mathrm{Ni}, \mathrm{Pb}, \mathrm{V}, \mathrm{Sb}$ and $\mathrm{Be}$ [7]. It is generally agreed that at the concentration levels of these metals in fertilizers, agricultural applications would not significantly increase total soil concentrations above background levels for decades although availability for root uptake into plants may increase.

There are currently no standards to monitor and regulate the application of livestock manure and other chemical inputs on farmers' fields in the Bambouto highlands. Consequently, it is difficult to conclude if current rates of application are above thresholds that would require remediation. Secondly, lack of investigation into contaminants in agricultural soils, derived from different agricultural activities in intensive agricultural areas makes it difficult to identify potential problems for certain agricultural practices. It is established that in Cameroon, there is an acute lack of comprehensive information on land contamination from economic and industrial development [16]. In the Bambouto highlands characterized by intensive agricultural practices, there is no comprehensive data on trace metal accumulation.

This study was undertaken with the following objec- tives:

1) To evaluate the status of trace metal in intensively cultivated inceptisols, and

2) To compare trace metal concentrations with toxicity thresholds for micronutrients.

\section{Materials and Methods}

\subsection{Description of the Study Area}

The study was carried out in Femok on the NE slope of the Bambouto highlands of Cameroon, The NE slope of Mount Bambouto is characterized by wet, humid and cool climate with perudic moisture regime (1700 to 1800 $\mathrm{mm}$ annual rainfall) and isothermic conditions $\left(15^{\circ} \mathrm{C}\right.$ to $18^{\circ} \mathrm{C}$ mean annual temperature), Tematio et al. [17]. The rainy season stretches from March to October and the drying season from November to February. The land use in this area consists of annual row cropping with rotational farming of maize, bean, potatoes, etc. [18].The soil has the following characteristics and is classified as TypicDystrandept. In general, mineral associations in the soil correspond to kaolinite, gibbsite, goethite, ferrihydrite, allophane and organometal complexes. Farmers use between 5.3 and $30 \mathrm{t} / \mathrm{ha}$ of poultry manure, 500 to 2000 $\mathrm{kg} / \mathrm{ha}$ NPK fertilizer and a wide range of pesticides and herbicides [1].

\subsection{Soil Sampling and Laboratory Analysis}

Thirty-six soil samples $(0-25 \mathrm{~cm})$ were collected within a $100 \mathrm{~m} \times 100 \mathrm{~m}$ grid cultivated by 10 farmers, using a stainless steel auger. The samples were air-dried at room temperature and crushed to pass through a $2 \mathrm{~mm}$ sieve. Sixteen soils were analyzed for the following properties: $\mathrm{pH}$, organic carbon, cation exchange capacity (CEC), Total $\mathrm{N}$ (totN), available $\mathrm{P}$, exchangeable $\mathrm{K}, \mathrm{Ca}$ and $\mathrm{Mg}$ and 36 samples for $\mathrm{Cu}, \mathrm{Mn}, \mathrm{Fe}$ and $\mathrm{Zn}$. Soil $\mathrm{pH}$ was determined by a $\mathrm{pH}$ meter with soil/water and soil/ $\mathrm{KCl}$ ratio of 1:2.5. Organic carbon was determined by Walkley and Black method [19] and total organic matter (OM) was calculated by multiplying the organic carbon by a factor of 1.724. Available P was extracted following the Bray 2 procedure. Bray- $2 \mathrm{P}$ was determined by shaking $2.5 \mathrm{~g}$ of air dry soil for one minute in $25 \mathrm{~mL}$ of a solution containing $0.03 \mathrm{~mol} \cdot \mathrm{L}^{-1} \mathrm{NH} 4 \mathrm{~F}$ and $0.1 \mathrm{~mol} \cdot \mathrm{L}^{-1} \mathrm{HCl}$ and measuring the $\mathrm{P}$ concentration in the solution by the colorimetric technique of Murphy and Riley (1962) [20]. The cation exchange capacity was (CEC) was determined by the ammonium saturation method [21]. Exchangeable bases $(\mathrm{Ca}, \mathrm{Mg}, \mathrm{K}$ and $\mathrm{Na}$ ) were extracted with $1 \mathrm{~N}$ ammonium acetate at $\mathrm{pH} 7$ and were determined by flame photometry. The concentrations of trace metals in the soil were extracted with Mehlich III extractant [22] and de- 
termined using atomic absorption spectrophotometer.

\subsection{Evaluation of Micronutrient Status of Typic Dystrandept}

The status of micronutrients was compared with soil critical levels (Table 1) and soil-based risk thresholds (Table 2). Trace element concentrations were declared deficient, sufficient or toxic.

\section{Results and Discussion}

The soils under potato-based cropping system were generally slightly acidic, of high organic and nitrogen status and adequate concentration of exchangeable bases and available P (Table 3). The acid nature of the soil indicates the availability of micronutrients, since most metals are free at this $\mathrm{pH}$ range.

Data on micronutrient status of intensively cultivated typic dystrandept soils is presented in Table 4. Relative to the critical levels presented in Table 1, 53\% and $8 \%$ of the soils examined were deficient in $\mathrm{Cu}$ and $\mathrm{Zn}$ respectively while $\mathrm{Fe}$ and $\mathrm{Mn}$ were in adequate supplies. High organic matter is expected to favor retention of micronutrient. The deficiency in $\mathrm{Zn}$ and $\mathrm{Cu}$ observed in some fields could be associated with high export of farm produce. Farmers in the Bambouto highland practice market gardening (Irish potato, leeks, carrot, beet root, cabbage

Table 1. Critical levels of $\mathrm{Fe}, \mathrm{Cu}, \mathrm{Mn}$ and $\mathrm{Zn}$ in soils based on Mehlich III extractant.

\begin{tabular}{cccc}
\hline Micronutrient & soil pH & Critical level & Reference \\
\hline $\mathrm{Fe}$ & & 4.8 & $\begin{array}{c}\text { Halvin and } \\
\text { Soltanpour [23] }\end{array}$ \\
$\mathrm{Cu}$ & & $0.5-0.6$ & Makarin and Cox [24] \\
$\mathrm{Mn}$ & $5.5-7.4$ & 3.0 & Baissa et al. [25] \\
$\mathrm{Zn}$ & & 1.4 & Cox and Wear [26] \\
\hline
\end{tabular}

Table 2. Soil-based risk threshold (toxicity) for micronutrients (in ppm).

\begin{tabular}{|c|c|c|c|c|}
\hline Micronutrient & xicityTo & $5 \leq \mathrm{PH}<6$ & $6 \leq \mathrm{PH}<7$ & $\mathrm{PH} \geq 7$ \\
\hline & \multicolumn{4}{|c|}{ Directive 86/178/EEC } \\
\hline $\mathrm{Cu}$ & $50-140$ & 40 & 50 & 100 \\
\hline \multirow[t]{2}{*}{$\mathrm{Zn}$} & $30-150$ & 100 & 150 & 250 \\
\hline & \multicolumn{4}{|c|}{ OSWER Directive 9285.7-69 } \\
\hline \multirow[t]{2}{*}{$\mathrm{Fe}$} & $100-500$ & & & \\
\hline & \multicolumn{4}{|c|}{ OSWER Directive 9285.7-71 } \\
\hline $\mathrm{Mn}$ & 202 & & & \\
\hline
\end{tabular}

Table 3. Soil chemical properties in intensively cultivated typic dystrandept.

\begin{tabular}{ccc}
\hline Soil property & Range & Mean \pm SE \\
\hline Organic carbon (\%) & $5.00-8.13$ & $6.70 \pm 0.23$ \\
Total N (\%) & $0.24-0.83$ & $0.60 \pm 0.03$ \\
C/N ratio & $7.29-31.92$ & $12.60 \pm 1.19$ \\
pH KCl (1:2.5) & $4.4-5.3$ & $5.0 \pm 0.06$ \\
pH water (1:2.5) & $5.0-6.3$ & $5.6 \pm 0.08$ \\
Available (Bray 2 P) (mg/kg) & $7.5-37.3$ & $26.00 \pm 2.12$ \\
Exchangeable bases (cmol $/ / \mathrm{kg})$ & & \\
Ca & $4.24-7.84$ & $6.4 \pm 0.29$ \\
$\mathrm{Mg}$ & $0.36-5.52$ & $2.2 \pm 0.31$ \\
$\mathrm{~K}$ & $0.33-0.66$ & $0.44 \pm 0.03$ \\
$\mathrm{CEC7}(\mathrm{cmol}+\mathrm{kg})$ & $26.7-36.0$ & $33.0 \pm 0.03$ \\
\hline
\end{tabular}

Table 4. Soil micronutrient (ppm) status.

\begin{tabular}{cccc}
\hline Micronutrient & Minimum & Maximum & SEM \pm Mean \\
\hline $\mathrm{Fe}$ & 32.64 & 108.52 & $2.48 \pm 58.59$ \\
$\mathrm{Cu}$ & 0.18 & 1.10 & $0.04 \pm 0.52$ \\
$\mathrm{Mn}$ & 14.42 & 95.85 & $2.72 \pm 29.20$ \\
$\mathrm{Zn}$ & 0.72 & 8.50 & $0.40 \pm 4.99$ \\
\hline
\end{tabular}

etc.) principally for export. Intensive cultivation for export leads to nutrient deficiency $[27,28]$. Zn deficiency is also common in poorly drained soils. Other causes of $\mathrm{Zn}$ and $\mathrm{Cu}$ deficiencies may be attributed to imbalance $\mathrm{Cu}$ and $\mathrm{Zn}$ in soil solution. High concentration of $\mathrm{Cu}$ in the soil solution relative to $\mathrm{Zn}$ can reduce the availability of $\mathrm{Zn}$ to a plant (and vice versa) due to competition for the same sites for absorption into the plant root [29]. Zinc deficiency in soils is also caused by high phosphorus status [29]. This may the case in Femok, with a high average $P$ status (Table 1).

The differences in $\mathrm{Zn}$ and $\mathrm{Cu}$ deficiency observed within the test area may be attributed to differences in origin of manure and composts used by farmers, past fertilizer use, and level of export of farm produce. Ayeni et al. [30] reported contrasting results (in two years) on the effect of source of poultry manure on soil micronutrient status in Nigeria. Generally, factors which affect $\mathrm{Zn}$ availability to plants include zinc content, $\mathrm{pH}$, organic matter content, clay content, calcium carbonate content, redox conditions, microbial activity in the rhizosphere, soil moisture status, concentration of other trace elements, concentrations of macro-nutrients, especially phosphorus 
and climate [29]. A common method employed to redress micronutrient deficiency, is the use of manure of plant and animal origins. Even then, the rate of application by some farmers may not be sufficient to reverse the negative micronutrient balance caused by continuous export of farm produce.

Zinc deficiency in soils and consequently crops has significant health implications. In 2002, Zn deficiency was included as a major risk factor in the global burden of diseases, and in 2004, WHO/UNICEF included Zn supplements in the treatment of acute diarrhea [34]. Deficiency in $\mathrm{Cu}$ in soils will negatively affect a number of physiological processes such as the photosynthetic and respiratory electron transport chains, metabolic pathways and ATP synthesis [35]. Although rare in humans, $\mathrm{Cu}$ deficiency can cause anaemia [36].

The status of the micronutrients in intensively cultivated typic dystrandept was lower than toxic thresholds prescribed by European Union and the United States Environmental Protection Agency (Table 2), except for Fe where $3 \%$ of the soils examined was potentially toxic (Fe $>100 \mathrm{ppm}$ ). Fe-toxicity occurs in poorly drained ironrich soils. Although iron $(\mathrm{Fe})$ is an essential nutrient for plant growth and development, it causes harm when present in excess and limited amounts [37]. For example, elevated concentrations lead to enhanced oxidative stress and the increased production of reactive oxygen species, known to favor diverse morphological, biochemical and physiological alterations. Excess $\mathrm{Fe}^{2+}$ in soil solution has been reported to affect the absorption of other nutrients such as Calcium $(\mathrm{Ca})$, Magnesium $(\mathrm{Mg})$, potassium $(\mathrm{K})$ and Phosphorus $(\mathrm{P})$ due to the precipitation of iron oxide in plant roots $[27,38,39]$. The overall consequence is reduced plant growth and total biomass. Some strategies adopted to reduce the effect of iron toxicity include proper drainage and balanced fertilization of plant nutrients. Despite the potential Fe-toxicity reported for 3\% of the soils examined, the results of this study indicate that farmers' current agricultural practices in the Bambouto highlands with respect to use of chemical inputs and manures, pose no threat to $\mathrm{Fe}, \mathrm{Mn}, \mathrm{Cu}$ and $\mathrm{Zn}$ toxicity.

\section{Conclusion and Recommendations}

The current study was undertaken to evaluate the micronutrient status ( $\mathrm{Fe}, \mathrm{Cu}, \mathrm{Mn}$ and $\mathrm{Zn}$ ) of soils in mount Bambouto and the necessity for remediation. Current use of pesticides, herbicides and animal manure in potatobased cropping systems on typic dystrandept soils is not at rates that would cause micronutrient toxicity and consequently environmental degradation. Instead, $\mathrm{Cu}$ deficiency is common in most of the fields $(53 \%)$ and to a less extent $(8 \%), \mathrm{Zn}$ deficiency. Because of the deficiency observed in $\mathrm{Cu}$ and $\mathrm{Zn}$ status in the soils, an analysis of spatial variability is required to guide site specific soil nutrient management. Furthermore, in order to obtain quality produce and protect the environment, a balanced fertilizer recommendation including NPK $+\mathrm{Cu}$ $+\mathrm{Zn}$ is required for intensively cultivated typic dystrandept soils in the Bambouto highlands.

\section{Acknowledgements}

We wish to thank the farmers of Femok, Bambouto highlands for permitting us to use their fields for this study and the anonymous reviewers of the submitted manuscript.

\section{REFERENCES}

[1] F. O. Tabi, D. Bitondo, G. S. Yinda, S. S. A. Kengmegne and M. Ngoucheme, "Effect of Long-Term Integrated Soil Fertility Management by Local Farmers on Nutrient Status of a Typic Dystrandepth under Potato-Based Cropping System," International research Journal of Agricultural Science and Soil Science, Vol. 3, No. 4, 2013, pp. 134-140.

[2] A. Yemmafouo, "Morcellement et Concentration Foncière: Des Réalités Complexes en Pays Bamiléké. L'exemple du Département des Bamboutos (Cameroun). Colloque International Les Frontières de la Question Foncière-At the Frontier of Land Issues," Montpellier, 2006, 16p.

[3] H. L. Premarathna, G. M. Hettiarachchi and S. P. Indraratne, "Trace Metal Concentration in Crops and Soils Collected from Intensively Cultivated Areas of Sri Lanka," Pedologist, 2011, pp. 230-240.

[4] M. Zovko and M. Romic, "Soil Contamination by Trace Metals: Geochemical Behaviour as an Element of Risk Assessment, Earth and Environmental Sciences," InTech, 2011.

http://www.intechopen.com/books/earth-and-environment al-sciences/soil-contamination-by-trace-metals-geochemi cal-behaviour-as-an-element-of-risk-assessment

[5] A. D. Hart, C. A. Oboh, C. S. Barimalaa and T. G. Sokari, "Concentration of Trace Metals (Lead, Iron, Copper and Zinc) in Crops Harvested in Some Oil Prospecting Locations in Rivers State, Nigeria," African Journal of Food and Nutritional Sciences, Vol.5, No. 2, 2005, pp. 1-21.

[6] A. R. Mermut, J. C. Jain, L. Song, R. Kerrich, L. Kosack and S. Jana, "Trace Element Concentrations in Selected Soils and Fertilizers in Saskatchewan, Canada," Journal of Environmental Quality, Vol. 25, No. 4, 1996, pp. 845853.

[7] S. O. Ajayi, B. O. Odesanya, A. O. Avwioroko, G. S. Adebambo and B. Okafor, "Effects of Long Term Fertilizer Use on Trace Metal Levels of Soils in a Farm Settlement," Journal of Agricultural Research and Development, Vol. 2, No. 2, 2012, pp. 44-51.

[8] S. Ogiyama, K. Sakamoto, H. Suzuki, S. Ushio, T. Anzai and K. Inubushi, "Measurement of Concentrations of Trace Metals in Arable Soils with Animal Manure Appli- 
cation Using Instrumental Neutron Activation Analysis and the Concentrated Acid Digestion Method," Soil Science and Plant Nutrition, Vol. 52, No. 1, 2006, pp. 114121. http://dx.doi.org/10.1111/j.1747-0765.2006.00013.x

[9] M. Ghanem, S. Samhan, E. Carlier and W. Ali, "Groundwater Pollution Due to Pesticides and Heavy Metals in North West Bank," Journal of Environmental Protection, Vol. 2, 2011, pp. 429-434.

http://dx.doi.org/10.4236/jep.2011.24049

[10] M. Muthusamy, B. K. Panigrahy, P. K. Shetty, A. Subbiah and R. Ravi, "Effect of Heavy Metal and Nutrient Uptake by Soils in Indian Cardamom Hills," Journal of Soil Science and Environmental Management, Vol. 3, No. 8, 2012, pp. 196-206.

[11] N. S. A. Bolan, A. A. Szogi, T. Chuasavathi, B. Seshadri, J. Rothrock Jr. and P. Panneerselvam, "Uses and Management of Poultry Litter," World's Poultry Science Journal, Vol. 66, No. 4, 2010, pp. 673-698. http://dx.doi.org/10.1017/S0043933910000656

[12] N. U. Benson, "Lead, Nickel, Vanadium, Cobalt, Copper and Manganese Distributions in Intensively Cultivated Floodplain Ultisol of Cross River, Nigeria," International Journal of Soil Science, Vol. 2, 2006, pp. 140-145.

[13] S. A. Mashi, S. A. Yaro and A. S. Haiba, "Cu, Mn, Fe and Zn Levels in Soils of Shika Area, Nigeria," Biomedical and Environmental Sciences, Vol. 17, No. 4, 2004, pp. 426-431.

[14] E. D. Udosen, N. U. Benson, J. P. Essien and G. A. Ebong, "Relation between Aqua-Regia Extractable Heavy Metals in Soils and Manihotutilissima within a Municipal Dumpsite," International Journal of Soil Science, Vol. 1, No. 1, 2006, pp. 27-32. http://dx.doi.org/10.3923/ijss.2006.27.32

[15] Y. Yahaya, U. A. Birnin-Yauri, B. U. Bagudo and S. S. Noma, "Quantification of Macro and Micro Elements in Selected Green Vegetables and Their Soils from Aliero Agricultural Fields in Aliero, Kebbi State, Nigeria," Journal of Soil Science and Environmental Management, Vol. 3, No. 8, 2012, pp. 207-215.

[16] O. Tening-Forton, V. E. Manga, A. S. Tening and A. V. Asaah, "Land Contamination Risk Management in Cameroon: A Critical Review of the Existing Policy Framework," Land Use Policy, Vol. 29, No. 4, 2012, pp. 750760. http://dx.doi.org/10.1016/j.landusepol.2011.11.011

[17] P. Tematio, L. Kengni, D. Bitom, M. E. Hodson, J. C. Fopoussi, H. G. Leumbe, H. G. Mpakam and D. Tsozue, "Soils and Their Distribution on Bambouto Volcanic Mountain, West Cameroon Highland, Central Africa," Journal of African Earth Sciences, Vol. 39, No. 3-5, 2004, pp. 447-457. http://dx.doi.org/10.1016/j.jafrearsci.2004.07.020

[18] P. S. Tsopjio, P. S. Jiomeneck, P. Tematio, M. A. Wilson and M. Yemefack, "Andosolization of Soils on a Strombolian Cone at Mount Bambouto, Cameroon," Open Journal of Soil Science, Vol. 1, 2011, pp. 97-105. http://dx.doi.org/10.4236/ojss.2011.13013

[19] E. Allison, “Organic Carbon," In: C. A. Black, Ed., Methods of Soil Analysis. Part 2, American Society of Agro- nomy, Madison, 1965, pp. 1367-1378.

[20] L. C. Blakemore, P. L. Searle and B. K. Day, "Methods for Chemical Analysis of Soils," New Zealand Soil Bureau, Scientific Report, NZ Soil Bureau, Lower Hutt, 1987, 80 pp.

[21] H. D. Chapman, "Cation Exchange Capacity," In: C. A. Black, Ed., Methods of Soil Analysis, Part 2, American Society of Agronomy, Madison, 1965, pp. 891-901.

[22] A. Mehlich, "Mehlich III Soil Test Extractant: A Modification of Mehlich II Extractant," Communications in Soil Science and Plant Analysis, Vol. 15, No. 12, 1984, pp. 1409-1416.

http://dx.doi.org/10.1080/00103628409367568

[23] J. L. Havlin and P. N. Soltanpour, "Evaluation of the NH4HCO3-DTPA Soil Test for Iron and Zinc," Soil Science Society of America Journal, Vol. 45, 1981, pp. 7075.

[24] A. K. Makarim and F. R. Cox, "Evaluation of the Need of $\mathrm{Cu}$ and Several Soil Extractants," Agron. J., Vol. 75, 1983, pp. 493-496.

http://dx.doi.org/10.2134/agronj1983.0002196200750003 $\underline{0018 \mathrm{x}}$

[25] T. Baissa, A. Suwanarit, Y. Ososapar and E. Sarobol, "Status of Mn, Fe, Cu, Zn, B and Mo in Rift Valley Soils of Ethiopia: Laboratory Assessment," Kasetsart Journal: Natural Science, Vol. 41, No. 1, 2007, pp. 84-95.

[26] F. R. Cox and J. I. Wear, "Diagnosis and Correction of Zn Problems in Corn and Rice Production," North Carolina State University Southern Coop. Bull., 1977, 222p.

[27] A. O. Olaleye, U. M. Ndubuaku and O. A. Dada, "Comparative study of the performance of jute plant (corchorusolitoriusl.) on Home Garden Soil, Farmland and Cocoa Plantation Soils as Influenced by Varying Levels of N-Fertilizer," Agro-Science Journal of Tropical Agriculture, Food, Environment and Extension, Vol. 7, No. 1, 2008, pp. 78-84.

[28] S. S. Dhaliwal, S. S. Walia, M. K. Walia and J. S. Manchanda, "Build Up of Macro, Micro and Secondary Plant Nutrients in Site Specific Nutrient Management Experiment under Rice-Wheat System," International Journal of Science, Environment and Technology, Vol. 2, No. 2, 2013, pp. 236-244.

[29] B. J. Alloway, "Zinc in Soils and Crop Nutrition," 2nd Edition, IZA and IFA Publishers, Brussels, 2008, 139p.

[30] L. S. Ayeni, E. O. Adeleye and O. P. Oso, "Residual Effect of Cocoa Pod Ash, Poultry Manure and NPK 20: 10:10 Fertilizer on Soil Nutrients, Nutrient Uptake and Yield of Maize (Zea mays)," Journal of Soil and Nature, Vol. 3, No. 2, 2009, pp. 4-9.

[31] B. M. Gawlik and G. Bidoglio, "Background Values in European Soils and Sewage Sludges," Results of a JRCCoordinated Study on Background Values. Part III. Conclusions, Comments and Recommendations, European Commission, 2006.

[32] US Environmental Protection Agency, "Ecological Soil Screening Level for Manganese. Interim Final OSWER Directive 9285.7-71," Office of Solid waste and Emer- 
gency Response, Washington DC, 2007.

[33] US Environmental Protection Agency, "Ecological Soil Screening level for Iron. Interim Final OSWER Directive 9285.7-69," Office of Solid Waste and Emergency Response, Washington DC, 2003.

[34] I. Tidemann-Andersen, H. Acham, A. Maage and M. K. Malde, "Iron and Zinc Content of Selected Foods in the Diet of School Children in Kumi District, East of Uganda: A Cross-Sectional Study," Nutrition Journal, Vol. 10, 2011, pp. 81-93.

http://dx.doi.org/10.1186/1475-2891-10-81

[35] B. Alaoui-Sossé, P. Genet, F. Vinit-Dunand, M. Toussaint, D. Epron and P. Badot, "Effect of Copper on Growth in Cucumber Plants (Cucumis sativus) and Its Relationships with Carbohydrate Accumulation and Changes in Ion Contents," Plant Science, Vol. 166, 2004, pp. 12131218. http://dx.doi.org/10.1016/j.plantsci.2003.12.032

[36] B. R. Stern, M. Solioz, D. Krewski, P. Aggett, T.-C. Aw, S. Baker, K. Crump, M. Dourson, L. Haber, R. Hertzberg, C. Carl Keen, B. Meek, L. Rudenko, R. Schoeny, W. Slob and T. Starr, "Copper and Human Health: Biochemistry,
Genetics, and Strategies for Modeling Dose-Response Relationships," Journal of Toxicology and Environmental Health, Part B, Vol. 10, 2007, pp. 157-222.

[37] J. M. Adamski, R. Danieloski, S. Deuner, E. J. B. Braga, A. S. Luis, de Castro and A. P. José, "Responses to Excess Iron in Sweet Potato: Impacts on Growth, Enzyme Activities, Mineral Concentrations, and Anatomy," ActaPhysiol Plant, Vol. 34, No. 5, 2012, pp. 1827-1836. http://dx.doi.org/10.1007/s11738-012-0981-3

[38] A. O. Olaleye, A. O. Ogunkunle, B. N. Singh, F. O. Odeleye, O. A. Dada and B. A. Senjobi, "Elemental Composition of Two Rice Cultivars under Potentially Toxic on Aquept and Aquent," NotulaeScientiaBiologicae, Vol. 1, No. 1, 2009, pp. 46-49.

[39] X. Zhang, F. Zhang and D. Mao, "Effect of Iron Plaque Outside Roots on Nutrient Uptake by Rice (Oryza sativa L.): Phosphorus Uptake," Plant and Soil, Vol. 209, No. 2, 1999, pp. 187-192. http://dx.doi.org/10.1023/A:1004505431879 